\title{
Meningkatkan attensi belajar siswa kelas awal melalui media visual
}

\author{
Husnul Khotimah ${ }^{1}$, Asep Supena ${ }^{2}$, Nandang Hidayat ${ }^{3}$ \\ ${ }^{1}$ Institut Pembina Rohani Islam Jakarta. Jalan Raya Klp. Dua Wetan No.1C, Jakarta Timur, 13730, Indonesia \\ ${ }^{2}$ Universitas Negeri Jakarta. Jalan Rawamangun Muka, RT.11/RW.14, Jakarta Timur, Jakarta 13220, Indonesia \\ ${ }^{3}$ Universitas Pakuan. Jalan Pakuan, Tegallega, Kecamatan Bogor Tengah, Kota Bogor, 16143, Indonesia \\ Email: husnul.khot1978@gmail.com, supena2007@yahoo.com, mr.nandanghidayat@gmail.com
}

\begin{tabular}{ll}
\hline \hline ARTICLE INFO & ABSTRACT \\
\hline \hline Article history: & Penelitian literatur ini bertujuan untuk mencari solusi terkait dengan upaya \\
Received: $29-12-2018 ;$ & meningkatan perhatian siswa khususnya ditingkat awal yaitu kelas 1, 2 dan 3 \\
Revised: $1-8-2019 ;$ & terhadap tugas belajarnya selama proses pembelajaran berlangsung \\
Accepted: $14-8-2019$ & menggunakan media pembelajaran visual. Penelitian ini menggunakan \\
Keywords: & metode tinjauan literatur integratif. Metode ini menggabungkan berbagai \\
perhatian; memori & artikel berbasis empiris dan penelitian, buku, dan literatur lain yang \\
penginderaan; media visual; & dipublikasikan tentang penggunaan media visual dalam meningkatkan perhatian \\
infografis; attention; sensing & belajar siswa kelas awal tersebut. Penelitian literatur ini menyimpulkan: (1) \\
memory; visual media; & Perhatian adalah proses pemilihan informasi yang dikontrol secara sukarela \\
infographics & oleh subjek (sadar), atau dapat karena pengaruh beberapa peristiwa eksternal \\
& yang ditangkap indera (tidak sadar); (2) Proses perhatian terjadi melalui \\
& seleksi, kesadaran, dan control; (3) Model media visual yang digunakan \\
& sebaiknya bervariasi baik media pembelajaran yang dibuat oleh guru maupun \\
& media dari internet. Media visual dalam bentuk infografis merupakan model \\
& media visual yang paling disarankan; (4) Implikasi dari fungsi media visual \\
& terhadap memori penginderaan antara lain: (a) memori pengindera hanya dapat \\
& mengolah informasi dalam jumlah terbatas, sehingga media visual yang \\
digunakan untuk menyajikan materi pembelajaran perlu didesain sedemikian & sehingga informasi-informasi kunci dapat diterima oleh siswa dengan baik; (b) \\
memori penginderaan yang memiliki daya serap paling tinggi adalah indera & penglihatan, sehingga mengkombinasikan sajian informasi visual dapat \\
meningkatkan jumlah informasi yang mampu diterima oleh memori pengindera.
\end{tabular}

This literature research aims to find solutions related to efforts to increase the attention of students, especially at the initial level, grades 1, 2 and 3 of their learning tasks during the learning process takes place using visual learning media. This study uses the method of review of integrative literature. This method combines various empirical and research-based articles, books, and other published literature on the use of visual media in increasing the attention of students learning in the early grades. This literature research concludes: (1) Attention is the process of selecting information that is voluntarily controlled by the subject (conscious), or it can be due to the influence of some external events that are sensed (unconscious); (2) The process of attention occurs through selection, awareness, and control; (3) The visual media model used should vary both the learning media made by the teacher and the media from the internet. Visual media in the form of infographics is the most recommended visual media model; (4) The implications of the function of visual media on sensing memory include: (a) memory sensors can only process information in a limited amount, so that the visual media used to present learning material needs to be designed so that key information can be received properly by students; (b) sensing memory that has the highest absorption power is the sense of sight, so combining visual information offerings can increase the amount of information that the sensory memory can receive. 


\section{PENDAHULUAN}

Perhatian adalah jelas dan subjektif dialami oleh semua orang sehat yang sadar, waspada, dan mampu setidaknya beberapa tingkat introspeksi (Cohen, 2014). Setiap hari kita dibombardir oleh sejumlah informasi baik di media cetak seperti koran, majalah, tabloid dan lainnya, maupun media elektronik seperti televisi, media sosial, dan lainnya. Kesemuanya itu menyita perhatian kita. Di kantor atau ditempat pekerjaan, kita diberi berbagai tugas yang menuntut perhatian kita. Di sekolah para siswa diminta untuk mengikuti proses pembelajaran dengan berbagai instruksi dan informasi dari guru yang harus menjadi perhatian mereka.

Ketika guru melaksanakan tugas pembelajaran baik di dalam maupun di luar kelas, guru seringkali dihadapkan pada masalah adanya bahkan relatif banyak siswa yang kurang perhatian terhadap penjelasan, instruksi, dan informasi yang disampaikannya (Purwatininghandayani, Wahyuni, \& Azis, 2019). Banyak siswa yang cenderung asik dengan aktivitasnya sendiri. Siswa cenderung lebih tertarik pada hal-hal lain yang diterima inderanya sehingga menyita perhatiannya.

Di era digital saat ini, hampir semua siswa baik di kelas awal maupun tinggi membawa smartphone ke sekolah. Kehadiran smartphone menambah kompleksnya permasalahan terkait dengan perhatian siswa dalam proses pembelajaran. Mekipun guru bahkan sekolah melarang siswa membuka smartphone pada saat proses pembelajaran, namun banyak diantara mereka yang kurang mengindahkan larangan tersebut. Keadaan seperti ini tentu saja kurang baik untuk mendukung terjadinya proses pembelajaran yang efektif. Jika guru tidak mampu mengendalikan perhatian para siswanya, maka proses pembelajaran sudah dapat dipastikan akan gagal mencapai tujuan.

Menghadap kondisi seperti ini berbagai strategi kreatif perlu dirancang guru untuk menarik perhatian siswanya agar lebih terkonsentrasi pada proses pembelajaran. Guru harus mampu mengarahkan siswa menggunakan kemampuannya untuk berpikir tentang tujuannya dan fokus perhatiannya. Guru harus memberinya informasi yang dibutuhkan untuk mencapai tujuannya, menyembunyikan informasi yang tidak relevan dengan pembelajaran, membimbing pilihan pergeseran fokusnya, dan itu semua dilakukan dengan cara yang tepat dan dan pada saat yang diperlukan.

Berkenaan dengan perhatian ini, para psikolog kognitif dan baru-baru ini juga neuropsikolog telah secara ekstensif mempelajari perhatian manusia (human attention). Berbagai penelitian dalam disiplin ini telah banyak dilakukan. Dalam disiplin ini, mekanisme perhatian telah dianggap dipandu oleh proses persepsi dan kognitif. Perhatian sebagai rangkaian proses yang memungkinkan dan membimbing pemilihan informasi perseptual yang diterima individu (Roda \& Thomas, 2006). Dalam hal ini, guru harus memahami bahwa siswa menerima melalui pengindraan satu set persepsi masukan secara bersamaan, baik persepsi masukan yang relevan dengan pembelajaran maupun di luar pembelajaran. Siswa bereaksi terhadap persepsi yang paling mungkin dari satu set persepsi tersebut, dan pada koridor inilah yang harus dimanfaatkan guru untuk mengarahkan perhatian siswanya.

Anak usia sekolah dasar pada kelas awal, umumnya belum dapat berkonsentrasi pada tugas belajarnya. Namun demikian, anak usia kelas awal cenderung mengalami kesulitan untuk mengarahkan perhatiannya kedalam tugas belajar yang harus diikutinya. Kondisi seperti ini menggangu jalannya proses pembelajaran, dan guru mengalami kesulitan dalam mengatasi masalah ini. Oleh karena itu, perlu dilakukan pengkajian mendalam untuk lebih memahami dan menemukan solusi terkait dengan upaya mangarahkan perhatian siswa pada tugas-tugas belajarnya. Kajian dalam penelitian ini lebih difokuskan pada penggunaan media pembelajaran visual.

Penelitian ini mengkaji isu-isu yang terkait dengan upaya peningkatan perhatian siswa sekolah dasar khususnya kelas awal terhadap tugas belajarnya selama proses pembelajaran berlangsung. Kajian difokuskan pada penggunaan media pembelajaran visual untuk meningkatkan perhatian siswa dalam belajar. Adapun masalah yang dibahas dalam artikel ini dirumuskan sebagai berikut: (1) Apa yang dimaksud dengan perhatian (attention); (2) Bagaimana peran media visual dalam pemrosesan informasi untuk meningkatkan perhatian siswa usia dini tehadap tugas belajarnya; (3) Model media visual bagaimana yang dapat membimbing, mengarahkan, dan memfokuskan perhatian siswa usia dini terhadap tugas belajarnya; (4) Bagaimana implikasi memori penginderaan melalui media visual terhadap peningkatan perhatian siswa usia dini dalam proses pembelajaran.

\section{METODE}

Penelitian ini merupakan penelitian kepustakaan menggunakan metode tinjauan literatur 
integratif. Dengan menggunakan metode tersebut, dilakukan penelaahan literatur melalui proses menganalisis, mengkritisi, dan mensintesis sejumlah literatur representatif mengenai topik yang relavan dengan masalah secara terintegrasi sedemikian rupa sehingga dihasilkan kerangka kerja dan perspektif baru (Callahan, 2010). Yaitu dalam hal ini permasalahan terhadap perhatian bagi anak-anak kelas awal. Anak yang berada di kelas awal adalah anak yang berada pada rentangan usia dini. Masa usia dini ini merupakan masa yang pendek tetapi merupakan masa yang sangat penting bagi kehidupan seseorang. Oleh karena itu, pada masa ini seluruh potensi yang dimiliki anak perlu didorong sehingga akan berkembang secara optimal. Metode ini menggabungkan berbagai artikel berbasis empiris penelitian, buku, dan literatur lain yang relavan dengan permasalahan yang dikaji.

\section{HASIL DAN PEMBAHASAN}

\section{Perhatian (Attention) pada Manusia}

Hasil penelusuran berbagai referensi ditemukan ternyata tidak ditemukan definisi perhatian atau atensi (attention) yang disepakati. Namun demikian, sebagian besar peneliti mengacu pada perhatian sebagai rangkaian proses yang memungkinkan dan membimbing pemilihan informasi persepsi yang masuk. Beberapa definisi perhatian menurut para peneliti diantaranya: perhatian berkaitan dengan pemrosesan pemilihan informasi yang masuk indera (Driver, 2001). Teori- teori psikologi kognitif memandang perhatian sebagai rangkaian proses yang memungkinkan dan membimbing pemilihan informasi persepsi yang masuk untuk membatasi rangsangan eksternal yang diproses oleh sistem kognitif yang terbatas agar tidak berlebihan (Driver, 2001; Roda \& Thomas, 2006). Kemampuan perseptual dan kognitif manusia adalah sumber daya yang terbatas. Perhatian adalah mekanisme yang digunakan untuk mengalokasikan sumber daya tersebut dengan cara yang paling efektif. Perhatian dapat dikontrol secara sukarela oleh subjek, atau dapat ditangkap oleh beberapa peristiwa eksternal. Mekanisme kontrol pertama disebut endogen, atau top-down, sasaran didorong oleh perhatian. (Roda \& Thomas, 2006). Perhatian sangat penting dalam mengoptimalkan sumber daya sistem yang terbatas. Sebagai proses selektif, perhatian menyediakan suatu organisme dengan representasi masukan sensorik yang dioptimalkan yang menekankan perincian yang relevan, kadang-kadang bahkan dengan mengorbankan representasi utama dari masukan sensorik (Attwell \& Laughlin, 2001).

Karakterisasi perhatian menyoroti banyak elemen penting: (1) orang-orang biasanya melaporkan bahwa objek fokus mereka berada di garis depan kesadarannya ketika mereka hadir; (2) objek atau informasi di mana perhatian terfokus biasanya menjadi lebih jelas dan lebih jernih dibandingkan dengan objek atau pemikiran lain yang mungkin; (3) proses ini melibatkan pemilihan satu dari berbagai rangsangan atau pemikiran yang mungkin pada saat tertentu; dan (4) ketika perhatian sangat terfokus, rangsangan yang tidak terkait lainnya berada di luar kesadaran dan tetap ada sampai ada pelepasan dari fokus utama perhatian (Cohen, 2014: 303). Perhatian adalah pemusatan tenaga psikis tertuju kepada suatu objek (spontan atau tidak spontan) dan banyak sedikitnya (intensitas) kesadaran yang menyertai sesuatu aktivitas yang dilakukan (Andi Thahir, 2014).

Tiga aspek perhatian yang secara umum diakui sebagai dasar, yaitu: seleksi, kesadaran, dan kontrol (Posner, 1993). Perhatian adalah proses selektif. Seleksi diperlukan karena ada batasan kapasitas untuk memproses informasi visual (Attwell \& Laughlin, 2001). Perhatian dikendalikan oleh tiga jaringan yang terkait dengan berbeda sistem otak: (1) mengingatkan (alerting), (2) berorientasi (orienting), dan (3) eksekutif (executive) (Petersen \& Posner, 2012). Perhatian merupakan pusat pengamatan yang menyebabkan meningkatnya kesadaran terhadap lingkungan stimuli yang terbatas (Gardiner \& Parkin, 1990). Perhatian merupakan sebuah konsep multi-dimensional yang digunakan untuk menggambarkan perbedaan ciri-ciri dan cara-cara merespons dalam sisitem kognitif. Dengan kata lain perhatian mengacu pada selektivitas persepsi. Dengan kesadaran, seseorang bisa hanya tertuju pada suatu objek/informasi dengan mengabaikan objek lainnya. Seperti seseorang yang ingin melihat penyanyi di panggung dengan mengabaikan orang-orang di sekitar panggung, saat ada sebuah pertunjukkan.

Perhatian memungkinkan pemilihan rangsangan dan tanggapan untuk pemrosesan kognitif berikutnya dan alokasi sumber daya kognitif (fokus), sering untuk jangka panjang (perhatian berkelanjutan). Ada empat elemen perhatian yaitu: 1) pemilihan sensorik; 2) fokus dan kapasitas; 3) niat tanggapan dan perhatian eksekutif; dan 4) perhatian berkelanjutan (Cohen, 2014). Perhatian menciptakan peta saliency terpadu, yaitu representasi topografi kekuatan stimulus relatif dan relevansi 
perilaku di ruang visual (Treue \& Katzner, 2010).

Chun and Wolfe (2001, p. 273) menjelaskan mekanisme seleksi informasi dalam perhatian: Pertama, perhatian dapat digunakan untuk memilih informasi yang relevan dengan perilaku dan atau mengabaikan informasi yang tidak relevan atau mengganggu. Kedua, perhatian dapat memodulasi atau meningkatkan informasi yang dipilih sesuai dengan keadaan dan tujuan dari pengindra. Dengan perhatian, penerima lebih dari penerima informasi pasif. Mereka menjadi pencari dan pengolah informasi aktif, mampu berinteraksi secara cerdas dengan lingkungan mereka.

Secara kasar dapat dikatakan bahwa perhatian dapat dikontrol secara sukarela oleh subjek, atau dapat ditangkap oleh beberapa peristiwa eksternal. Jenis mekanisme kontrol yang pertama disebut sebagai perhatian endogen, top-down, atau goal driven (Arvidson, 2003). Perhatian endogen adalah perhatian yang diberikan ketika kita sedang membaca suatu halaman buku karena didorong oleh rasa ingin tahu sesuai dari buku tersebut. Sementara itu, mekanisme sebaliknya adalah exogenous, bottomup, atau stimulus-driven. Misalnya, perhatian beralih dari kita beralih dari buku yang sedang dibaca karena ada suara yang terdengar tiba-tiba. Kedua mekanisme ini memiliki karakteristik yang berbeda, Perhatian endogen bersifat sukarela, penuh usaha, dan memiliki waktu yang lambat (berkelanjutan), sementara perhatian eksogen menarik perhatian secara otomatis dan memiliki waktu yang cepat dan bersifat sementara waktu (Chun \& Wolfe, 2001, p. 279).

Broadbent (dalam Roda \& Thomas, 2006) mengemukakan bahwa seleksi berlangsung dalam dua tahap: satu yang paksaan, dan satu yang penuh perhatian. Pertama, tahap paralel (beberapa rangsangan dapat diproses pada waktu yang sama) mengkode sifat-sifat fisik sederhana dari rangsangan yang masuk. Pengakuan sifat fisik sederhana memungkinkan seseorang untuk menyaring semua rangsangan yang tidak relevan (tanpa pengawasan) dan hanya meneruskan rangsangan yang dipilih ke tahap kedua. Tahap kedua, serial, penuh perhatian ini hanya mampu memproses terbatas dan mengkode lebih banyak sifat abstrak seperti semantik stimulus yang diterima.

Beban kognitif memainkan peran penting dalam menentukan berapa banyak informasi yang dipertahankan ketika siswa melakukan lebih dari satu tugas pada satu waktu (Lee, Lin, \& Robertson, 2012). Kemungkinan meningkatkan kontrol perhatian melalui intervensi yang ditargetkan, baik itu pelatihan terkomputerisasi atau teknik pengaturan diri, sekarang sudah mapan (Cardoso-Leite \& Bavelier, 2014).

Jika dikaitkan dengan perkembangan anak, ada empat aspek perhatian yang berkembang seiring dengan bertambah besarnya anak. (1) Ketika anak-anak tumbuh semakin besar, ia lebih mampu mengendalikan perhatiannya. (2) Seiring dengan perkembangannya, anak-anak menjadi lebih baik dalam menyesuaikan kemampuan perhatianya dengan tegas. (3) Anak-anak mengembangkan kemampuannya untuk merencanakan bagaimana ia akan mengarahkan perhatiannya. (4) Anak-anak mengembangkan kemampuan mereka untuk memonitor perhatiannya.

Perkembangan perseptual anak kelas awal khususnya perhatian terjalin dengan aspek perkembangan lain. Jadi permasalahan yang terjadi dalam perkembangan perseptual anak dapat berdampak negatif pada aspek-aspek lain. Perkembangan perhatian anak kelas awal ini masih mengalami penajaman dan penghalusan. Oleh karena itu guru harus memberi perhatian pada aspek perkembangan perhatian anak. Sebagai guru kelas awal banyak hal yang terjadi di dalam kelas yang membuat kita selalu berfikir untuk memberikan yang terbaik. Mereka anak-anak usia dini membutuhkan suasana belajar yang asyik dan menyenangkan, Sehingga guru dituntut untuk mengembangkan ide-ide kreatif dalam meningkatkan kualitas belajar. Dalam hal ini, anak-anak usia dini akan berkembang dengan baik jika dirangsang dan difungsikan melalui interaksi dengan lingkungan melalui teknik visualisasi.

Dari kajian berbagai pandangan dan hasil penelitian di atas dapat disimpulkan bahwa perhatian adalah proses pemilihan informasi yang dikontrol secara sukarela oleh subjek, atau dapat karena pengaruh beberapa peristiwa eksternal yang ditanggkap indera. Perhatian dapat mengubah niat (intention), dan niat merupakan pusat konsep tindakan sukarela. Proses perhatian terjadi melalui seleksi, kesadaran, dan kontrol.

\section{Pemanfaatan Media Pembelajaran Visual untuk Meningkatkan Perhatian Siswa}

Media adalah perantara atau pengantar pesan dari pengirim ke penerima pesan. Secara umum media visual dikelompokkan menjadi media gambar representasi (gambar dan foto), diagram yang menunjukkan hubungan antar konsep dan isi materi, peta yang menunjukkan hubungan antar unsur 
dalam isi materi, dan grafik (tabel, grafik, chart) (Jatmika, 2015). Media pembelajaran adalah sebuah alat yang berfungsi untuk menyampaikan pesan pembelajaran (Arsyad, 2005; Hermawan, Samsuri, Kurniawati, Sofyaningsih, \& Prasetyo, 2019). Media pembelajaran adalah segala sesuatu yang dapat digunakan untuk menyalurkan informasi dan segala sesuatu yang dapat dimanfaatkan untuk memperjelas materi atau mencapai tujuan pembelajaran (Iswidayati, 2010). Dengan demikian, media pembelajaran adalah segala sesuatu yang dapat digunakan sebagai medium untuk mengantarkan atau mengkomunikasikan pesan dari sumber (guru) kepada penerima (siswa).

Media pembelelajaran dapat diklasifikasikan berdasarkan teknik yang dipergunakan dalam pembuatan media, cara yang dipergunakan untuk mengirimkan pesan, bentuk informasi yang digunakan, atau tingkat kekonkritan dan keabstrakannya seperti kalsifikasi menutut Edgar Dale. Jika diklasifikasikan berdasarkan bentuk informasi yang digunakan, media pembelajaran dapat diklasifikasikan dalam kategori media visual diam, media visual gerak, media audio, media audio visual diam, dan media audio visual gerak. Klasifikasi media ini dapat menjadi landasan untuk membedakan proses yang dipakai untuk menyajikan pesan, bagaimana suara dan atau gambar itu diterima, apakah melalui penglihatan langsung, proyeksi optik, proyeksi elektronik atau telekomunikasi. Klasifikasi menurut tingkat dari yang paling konkrit sampai yang paling abstrak sebagaimana dikemukakan Edgar disajikan pada Gambar 1.

People Generally
Remember:

\section{Gambar 1. Kerucut Pengalaman Elgard Dale (https://civitas.uns.ac.id/aprinnikma h/2017/05/15/kerucut-pengalaman- edgar-dale/)}

Manusia memiliki organ penginderaan yang berfungsi untuk menangkap rangsangan. Organ pengindraan ini sering diasebut panca indra. Pada setiap indera memiliki daya serap yang berbeda mengenai stimulus yang diterimanya. Wiroatmojo dan Sasonohardjo (2002) mengemukan bahwa daya serap panca indera adalah sebagai berikut: indera persentase daya serap penglihatan $82 \%$, pendengaran $11 \%$, peraba $3,50 \%$, perasa $2,50 \%$, dan penciuman $1 \%$. Hal ini menunjukkan bahwa indera yang paling tinggi kemampuan daya serapnya terhadap informasi yang diterima atau diindera adalah indera penglihatan dan disusul dengan indera pendengaran. Oleh karena itu, dalam kaitan dengan proses pembelajaran, kemampuan daya serap penglihatan ini harus dimanfaatkan untuk meningkatkan hasil belajar melalui penggunaan media visual. Namun, jika memungkinkan pembelajaran dapat memanfaatkan semua indera tersebut melalui berbagai media secara variatif sehingga daya serap siswa akan materi pembelajaran optimal.

Visualisasi adalah menterjemahkan imej-imej mental dalam bentuk lisan ataupun grafik (Mohd Safarin Nordin \& Muhammad Sukri Saud, 2006). Sejumlah penelitian terhadap otak manusia mendukung bahwa pembelajaran dapat terjadi lebih maksimal dengan teknik visualisasi (Kolb \& Whishaw, 2014). Imajinasi dalam teknik visualisasi bisa menjadi sangat efektif untuk pembelajaran karena banyak bagian di otak yang aktif dan memperkuat jalinan- jalinan saraf yang berhubungan 
dengan kegiatan yang sedang dibayangkan. Imajinasi berkolaborasi dengan indera visual bersama-sama menciptakan keharmonisan dan keselarasan secara detail dan lengkap. Berbagai teknik visualisasi digunakan untuk memotivasi kepercayaan diri, kesiapan mental untuk bersaing, dan belajar demi peningkatan keahlian.

Schmidt \& Vandewater (2008) menjelaskan bahwa berdasarkan hasil penelitian Gavriel Salomon, berbagai bentuk media pembelajaran menghadirkan dan mengembangkan proses kognitif yang berbeda. Pemaparan berulang terhadap kode sinematik yang disajikan dalam film, seperti teknik zoom, menuntun anak-anak untuk menginternalisasi kode-kode tersebut dan meningkatkan capaian hasil belajarnya. Sejumlah hasil studi menemukan manfaat video game untuk perhatian visual, termasuk kapasitas perhatian yang lebih besar, penyebaran perhatian yang lebih cepat, dan pemrosesan yang lebih cepat. Salah satu keprihatinan yang berkembang adalah apakah penggunaan media elektronik berkaitan dengan gangguan attention deficit hyperactivity (ADHD) (Schmidt \& Vandewater, 2008).

Media yang digunakan dalam kegiatan pembelajaran dapat mempengaruhi efektivitas pembelajaran (Brown dalam Iswidayati, 2010). Pembelajaran berbantuan multimedia efektif meningkatkan minat belajar siswa (Sutikno \& Isa, 2010). Penggunaan multimedia interaktif berpengaruh terhadap hasil belajar siswa (Nusir, Alsmadi, Al-Kabi, \& Sharadgah, 2013). Terdapat interaksi antara media pembelajaran dengan minat belajar terhadap capaian hasil belajar (Supardi, Leonard, Suhendri, \& Rismurdiyati, 2015).

Berdasarkan kajian sejumlah hasil penelitian di atas menunjukkan bahwa penggunaan media pembelajaran terutama media yang menekankan pada pemanafaatan indera penglihatan atau visual memberikan pengaruh terhadap perhatian siswa dalam belajar yang akhirnya bermuara pada capaian hasil belajar yang lebih baik. Oleh karena itu, penggunaan media visual dalam pembelajaran khususnya untuk siswa kelas awal perlu terus ditingkatkan. Berkaitan dengan hal tersebut, guru dituntut untuk mengembangkan kemampuan dalam membuat berbagai macam media visual, melakukan pencarian dari media internet media visual yang relevan dengan bahan ajar, dan menggunakannya secara tepat dalam proses pembelajaran.

\section{Perhatian dan Peran Media Visual dalam Pemrosesan Informasi}

Dalam kegiatan pembelajaran, guru dan siswa saling berinteraksi dan dalam komunikasi dua arah. Guru bertindak sebagai pemberi pesan menyampaian pesan berupa bahan ajar, tugas, laitihan, atau lainnya dengan memanfaatkan media tertentu kepada siswa sebagai penerima pesan. Media pembelajaran visual yang interaktif digunakan diantaranya untuk menghindari terjadinya komunikasi verbal. Kelemahan dari bentuk komunikasi verbal adalah sangat dipengaruhi oleh pemberi informasi, penerima informasi, dan lingkungan tempat terjadinya komunikasi. Terkadang siswa salah menafsirkan apa yang disampaikan guru, mereka tidak memahami perintah atau materi yang disampaikan yang salah satunya disebabkan oleh gangguan dari luar. Gangguan ini lazim disebut dengan barriers atau noise. Dalam mengatasi kendal-kendala itu dalam proses komunikasi ini perlu dibantu dengan media visual yang interaktif. Karena siswa akan lebih memahami apa yang disampaikan dengan melihat media visual yang dipergunakan oleh guru. Pesan yang disampaikan oleh guru berupa simbol-simbol komunikasi (encoding) yang akan diterjemahkan oleh siswa menjadi suatu pesan (decoding). Pemanfaatan media visual yang interaktif akan membantu memfokuskan perhatian siswa sehingga informasi yang disampaikan guru dapat dipersikan atau diterjemahkan siswa dengan tepat. Jika ini terjadi maka proses pembelajaran akan berjalan dengan lebih berkualitas dan hasil belajar akan dicapai secara efektif.

Memori penginderaan (sensory memory) adalah komponen paling pertama yang menerima informasi dalam sistem pemrosesan informasi dalam struktur memori pada otak manusia. Untuk memberikan persepsi dan identifikasi awal informasi yang diterima, memori ini mengubah informasi dalam bentuk signal- signal stimulus. Hasil penelitian menunjukkan bahwa memori ini menahan signalsignal tersebut untuk memberikan persepsi dan identifikasi dalam waktu yang sangat pendek (kurang dari satu mikro detik) dan signal tersebut akan segera hilang dari memori ini karena datangnya signalsignal stimulus berikutnya (Bruning, Schraw, \& Norby, 2011). Struktur memori manusia dan pemrosesan informasi disajkan pada gambar 2.

Memori penginderaan merupakan suatu sistem yang terdiri dari penerima atau penerus informasi (sense registers). Penerima informasi dikenal dengan alat pengindera, seperti mata (untuk melihat dan menerima pandangan/informasi visual), telinga (untuk mendengar dan menerima 
suara/informasi auditori), hidung (untuk membau), lidah (untuk merasa) dan kulit (untuk meraba). Meskipun setiap alat pengindera tersebut mempunyai kemampuan yang berbeda, sebagian besar peneliti lebih memfokuskan pada penglihatan dan pendengaran.

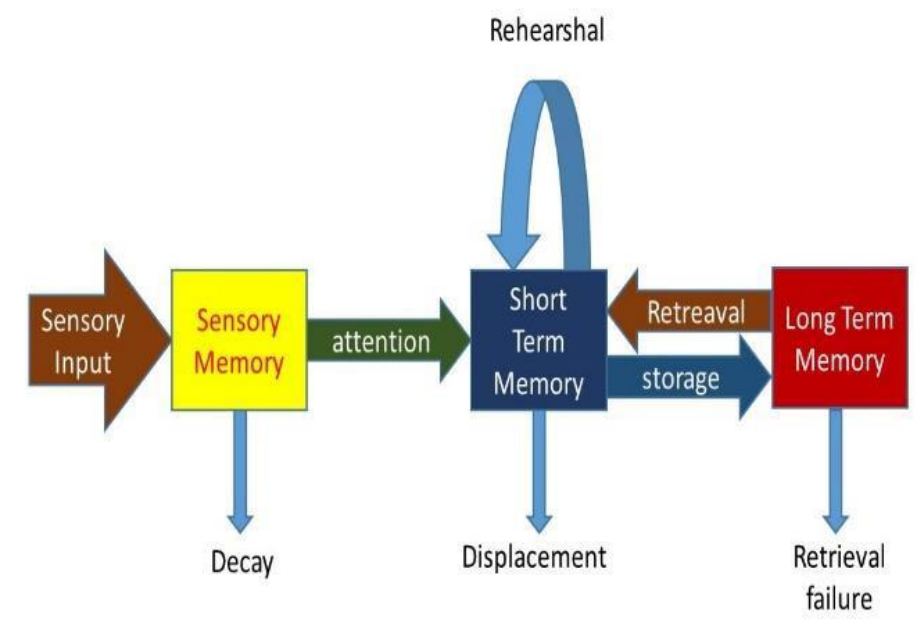

Gambar 2. Struktur Memori (Atkinson \& Shiffrin, 2016)

Ada tiga proses yang terjadi ketika memori pengindera menerima suatu informasi: perhatian, persepsi atau pengenalan pola dan pemberian makna. Perhatian adalah langkah 3 pertama yang dilakukan oleh memori pengindera untuk mendeteksi dan memperhatikan datangnya suatu stimulus. Seseorang memberikan perhatian terhadap suatu informasi dengan mengalokasikan muatan kognitif terhadap informasi tersebut. Pemberian perhatian terhadap datangnya suatu informasi dapat terjadi secara otomatis (tidak sadar) maupun secara sadar (disengaja), tergantung dari pengetahuan awal yang tersedia di memori jangka panjang. Pengetahuan awal (prior knowledge) adalah informasi yang sebelumnya telah dipelajari dan disimpan di memori jangka panjang. Dalam hal ini, media pembelajaran visual yang digunakan akan membantu mengarahkan perhatian sadar siswa dan mengaitkan pengetahuan awalnya dengan informasi baru yang diterimanya lewat penginderaan.

Di dalam memori penginderaan, informasi yang dipilih dan menjadi perhatian diuraikan menjadi sinyal-sinyal yang akan dipersepsikan dengan mengenali polanya, tanpa perlu memahami maknanya, menggunakan pengetahuan awal. Pengetahuan awal ini dapat berupa prototype, analisis bentuk atau deskripsi suatu bentuk. Pengetahuan awal ini stimulus. Apabila perhatian untuk mengindera stimulus tersebut ditingkatkan, maka alat pengindera akan mengumpulkan lebih banyak informasi yang berkaitan dan mengabaikan informasi yang tidak berkaitan. Kemudian, sistem ini akan mengirimkan ke sistem memori berikutnya (working memory) untuk memberikan dan mengorganisasikan makna informasi tersebut. Memori penginderaan tidak berfungsi untuk mempelajari informasi, tetapi memperhatikan informasi dan mengenali polanya.

Struktur ingatan dapat dibedakan menjadi tiga sistem, yaitu sistem ingatan sensorik (sensory memory), sistem ingatan jangka pendek (short term memory), sistem ingatan jangka panjang (long term memory) (Schraw \& McCrudden, 2013).

Memorisensori mencatat informsiatau stimuli yang masuk melalui salah satuatau kombinasi dari panca indra, yaitu secara visual melalui indera penglihatan, mendengar melalui indera pendengaran, bau melalui indera penciuman, rasa melalui indera pengecapan, dan rabaan melalui indera perasa/peraba. Bila informasi atau stimuli tersebut tidak diperhatikan akan langsung terlupakan, namun bila diperhatikan maka informasi tersebut ditransfer ke sistem ingatan jangka pendek. Sistem ingatan jangka pendek menyimpan informasi atau stimuli selama 30 detik, dan hanya sekitar tujuh bongkahan informasi (chunks) yang dapat disimpan dan dipelihara di dalam sistem memori jangka pendek dalam suatu saat (Bhinnety, 2008).

Visualisasi otak manusia mampu memodifikasi susunan sarafnya yang disebut neuro-plasticity dengan memfokuskan sumberdaya yang ada dan mengembangkannya di korteks, sehingga stimulasi yang ditimbulkan dari proses visualisasi akan membuat otak menjadi lebih mahir dalam melakukan aktivitas yang dipelajari. Pengulangan konsepsi perseptual dan konseptual serta beberapa bentuk pengkondisian. akan meningkatkan kemampuan sesuai konten yang dipelajari. 
Media visual dapat membantu meningkatkan perhatian siswa dalam belajar. Imajinasi yang dilakukan berulang-ulang juga memiliki pengaruh yang sama. Kemampuan otak dalam meningkatkan tingkat lewat repetisi disebut memori prosedural. Beberapa area otak yang terkait saat seseorang sedang belajar meningkatkan memori proseduralnya adalah: basal ganglia, hippocampus, cerebellum, neostriatum (Gabrieli, 1998). Aktivitas kompleks yang dilakukan secara berulang-ulang akan menciptakan otomatisasi sistem saraf yang terkait yang penting untuk pengembangan kognitif dan keahlian motorik. (Moscovitch, 1992). Artinya, pencapaian hasil belajar membutuhkan pratek yang berulang-ulang dan belajar meningkatkan penguasaannya seiring waktu. Pengalaman belajar ini akan meningkatkan kecepatan pemrosesan informasi secara internal dan mendata input eksternal, mengembangkan wawasan dan penyimpanan pengetahuan, serta pada akhirnya akan menguatkan kapasitas otak dalam melakukan efisiensi dan melaksanakan aktivitas yang dipelajari secara lebih optimal. Media visualisasi menjadi sangat berharga dalam proses belajar dan penguasaan penguasaan kompetensi sebagai bentuk hasil belajar.

Pada saat siswa melakukan penginderaan suatu peristiwa atau aktivitas yang divisualisasikan melalui media pembelajaran visual, sinyal-sinyal saraf yang aktif akan bereaksi seolah-olah ia berada dalam peristiwa atau melakukan aktivitas yang divisualisasikan. Respons otak akan menyamakan bayangan dengan kenyataan. Neuron-neuron yang terkait dalam proses visualisasi akan menguatkan koneksi sinapsis (hebbian synapses) serta memori prosedural yang diperlukan dalam melakukan aktivitas yang sedang dilatih (Kolb \& Whishaw, 2014).

Teknik visualisasi sangat berharga dan bermanfaat dalam proses pembelajaran terutama dalam pemusatan atau konsentrasi belajar siswa yang dikenal dengan atensi/perhatian. Dalam proses pembelajaran, siswa tidak pernah lepas dari perhatian, baik dari hal yang kecil sampai hal yang besar. Pemusatan perhatian sangat penting dalam pebelajaran, karena dengan perhatian rasa ingin tahu siswa akan meningkat. Dalam perhatian terjadi aktivitas jiwa yang melibatkan otak dan indera. Perhatian merupakan pemusatan atau konsentrasi dari seluruh aktivitas individu yang ditujukan kepada sesuatu atau sekumpulan objek dan mengubah penampilan sehingga meningkatkan kontras stimulus yang jelas (Carrasco, Ling, \& Read, 2004).

Implikasi dari fungsi memori penginderaan ini terhadap proses pembelajaran antara lain: (1) memori pengindera hanya dapat mengolah informasi dalam jumlah terbatas, sehingga penyajian materi pembelajaran perlu didesain sedemikian sehingga informasi-informasi kunci dapat diterima oleh siswa dengan baik; (2) memori penginderaan dapat menerima informasi dari kelima alat indera, sehingga mengkombinasikan sajian informasi, misalnya, visual (tertulis) dan verbal, dapat meningkatkan jumlah informasi yang mampu diterima oleh memori pengindera.

\section{Ragam Media Visual}

Menurut Sudjana dan Rivai (2002), pengajaran akan lebih efektif apabila objek dan kejadian yang menjadi bahan pengajaran dapat divisualisasikan secara realistik menyerupai keadaan yang sebenarnya, namun tidaklah berarti bahwa media harus selalu menyerupai keadaan yang sebenarnya. Media pembelajaran untuk siswa kelas awal sangat diperlukan karena menurut teori perkembangan intelektual Piaget, tarap perkembangan anak pada usia ini masih pada taraf operasional konkret. Oleh karena itu, guru harus selalu berusaha menyiapkan media pembelajaran untuk setiap topik pembelajaran. Media visual yang digunakan sebagai media pembelajaran dapat disiapkan atau dibuat sendiri oleh guru atau memenfaatkan media visual yang tersedia di jejering internet.

\section{Media yang Disiapkan Sendiri oleh Guru}

Media yang disiapkan guru dapat berupa media visual dibuat sendiri oleh guru sesuai dengan bahan ajar. Media tersebut dapat berupa:

Objek sesungguhnya

Objek atau benda sesungguhnya dapat dijadikan media visual jika objek tersebut memungkikan untuk dihadirkan di dalam kelas. Dalam pembelajaran media berupa objek sesungguhnya akan lebih menarik sehingga dapat mendorong dan menjaga perhatian siswa selama proses pembelajaran berlangsung.

Objek tiruan 
Guru dapat membuat tiruan dari objek sesungguhnya untuk dijadikan alat peraga jika objek sesungguhnya tidak mungkin dihadirkan dalam kelas.

Media cetak

Guru dapat mengubah bahan ajar kedalam bentuk media visual dalam bentuk gambar baik yang dibuat secara manual atau dibuat menggunakan aplikasi yang tersedia di komputer kemuadian dicetak atau diprint. Dalam upaya pembuatannya, guru dapat meminta bantuan orang lain yang memiliki keahlian yang dibutuhkan.

\section{Media Digital}

Guru dapat menyajikan bahan ajar dalam bentuk media visual gambar, film atau video animasi, komik, atau bentuk lain secara digital. Penyajian media visual digital dalam proses pembelajaran membutuhkan komputer dan proyektor. Dalam upaya pembuatannya, guru dapat meminta bantuan orang lain yang memiliki keahlian dalam mengubah bahan ajar ke dalam bentuk digital. Salah satu contoh adalah pemanfaatan Macromedia Flash 8 untuk memvisualisasikan bahan ajar secara digital yang memberi kesan realistik. Aplikasi ini memiliki kemampuan menjadikan suatu obyek dapat terlihat lebih hidup dan lebih nyata sehingga sangat potensial untuk dijadikan sebagai media pembelajaran untuk menciptakan pembelajaran yang lebih menarik dan efektif.

\section{Memanfaatkan Media Visual yang Tersedia di Internet}

Di era digital saat ini media visual dapat diperoleh secara mudah dengan berselencar memanfaatkan teknologi internet. Data visual telah berkembang pesat sejak kumpulan gambar pertama didigitalkan. Evolusi ini telah terjadi di semua aspek penyimpanan, pengiriman, dan pemahaman. (Huang, Le, Paine, Khorrami, \& Tariq, 2014). Pada saat ini dunia data visual berkembang sangat dramatis. Berbagai infografis seperti gambar, foto, video, film, dan beragam media digital bentuk lainnya bertebaran dan dapat dengan mudah diakses. Untuk itu, optimalisasi pemanfaatan media visual dari internet untuk meningkatkan perhatian siswa dalam belajar merupakan keniscayaan. Berikut beberapa media visual yang dapat dimanfaatkan guru sebagai media dalam pembelajaran.

Infografis adalah cara penyampaian informasi yang cukup efektif. Infografis merubah data-data teks menjadi mudah dimengerti lewat berbagai teknik visualisasi data yang menarik. Penyajian bahan ajar menggunakan media infografis dapat membantu siswa sebagai penerima pesan untuk mempersepsi dan memahami konsep-konsep yang kompleks secara lebih mudah dan cepat. Infografis adalah informasi yang disajikan dalam bentuk grafis. Lankow, Ritchie, Crooks, \& Ross (2014) mengemukakan bahwa keunggulan komunikasi visual melalui infografis antara lain: visualisasi gambar mampu menggantikan penjelasan yang terlalu panjang, serta menggantikan tabel yang rumit dan penuh angka. Mata manusia lebih cepat menangkap informasi yang tersaji dalam bentuk visual (grafis) daripada dalam bentuk tekstual, lalu kemudian cenderung menaruh perhatian lebih besar untuk membaca isi pesan yang disampaikan. Perpaduan animasi, gambar kreatif dan musik dapat membangun sebuah interaksi positif dalam memahami pesan yang ingin disampaikan.

Inforgrafis dapat dikelompokkan menjadi dua, yaitu:

Infografis statis

Infografis statis adalah infografis yang disajikan dalam bentuk visual statis, tanpa konsep audio atau konsep animasi yang bisa bergerak. Jenis infografis yang satu ini bisa dibilang merupakan jenis yang paling sederhana dan paling sering digunakan untuk berbagai kebutuhan.

Infografis Animasi

Infografis Animasi dikenal juga dengan sebutan animated infographics. Infografis jenis ini bisa digunakan pada media audio visual seperti televisi atau youtube. Infografis animasi bisa disajikan dalam bentuk 2 dimensi maupun bentuk 3 dimensi yang tampak lebih kompleks. Melihat data dan informasi yang disajikan dengan infografis animasi jadi terasa menyenangkan seperti menonton film.

Infografis interaktif

Infografis interaktif adalah jenis infografis yang paling kompleks jika dibandingkan dengan infografis statis dan infografis animasi. Pada infografis ini, target yang menjadi sasaran penyajian 
Husnul Khotimah, Asep Supena, Nandang Hidayat

informasi bisa melakukan interaksi terhadap infografis yang disajikan.

\section{SIMPULAN}

Penelitian literature ini menghasilkan empat kesimpulan: Pertama, perhatian adalah proses pemilihan informasi yang dikontrol secara sukarela oleh subjek (sadar), atau dapat karena pengaruh beberapa peristiwa eksternal yang ditangkap indera (tidak sadar). Kedua, proses perhatian terjadi melalui seleksi, kesadaran, dan kontrol. Penggunaan media pembelajaran terutama media yang menekankan pada pemanfaatan indera pengilihatan atau visual memberikan pengaruh terhadap perhatian siswa dalam belajar yang akhirnya bermuara pada capaian hasil belajar yang lebih baik. Ketiga, model media visual yang digunakan sebaiknya bervariasi baik media pembelajaran yang dibuat oleh guru sendiri maupun media yang diambil dari internet. Media visual dalam bentuk infografis merupakan model media visual yang paling disarankan. Keempat, implikasi dari fungsi media visual terhadap memori penginderaan antara lain: (1) memori pengindera hanya dapat mengolah informasi dalam jumlah terbatas, sehingga media visual yang digunakan untuk menyajikan materi pembelajaran perlu didesain sedemikian sehingga informasi-informasi kunci dapat diterima oleh siswa dengan baik; (2) memori penginderaan dapat menerima informasi dari kelima alat indera tetapi daya serap paling tinggi adalah indera penglihatan, sehingga mengkombinasikan sajian informasi visual yang dapat meningkatkan jumlah informasi yang mampu diterima oleh memori pengindera.

\section{UCAPAN TERIMAKASIH}

Rasa syukur dan ucapan terimakasih yang sebesar-besarnya kepada semua pihak yang telah dengan ikhlas membantu proses pembuatan penelitian literatur ini. Ucapan terima kasih tak terhingga disampaikan kepada yang terhormat Dr. Asep Supena, selaku dosen pengampu matakuliah Neuropsikologi dan seluruh Pengelola Perpustakaan Program Pascasarjana Universitas Negeri Jakarta.

\section{DAFTAR PUSTAKA}

Arsyad, A. (2005). Media pembelajaran. Jakarta: Raja Grafindo Persada.

Arvidson, P. S. (2003). A lexicon of attention: From cognitive science to phenomenology. Phenomenology and the Cognitive Sciences. https://doi.org/10.1023/A:1024895827774

Atkinson, R. C., \& Shiffrin, R. M. (2016). Human memory: A proposed system and its control processes. Scientists Making a Difference: One Hundred Eminent Behavioral an Brain Scientists Talk about their Most Important Contributions. https://doi.org/10.1017/CBO9781316422250.025

Attwell, D., \& Laughlin, S. B. (2001). An energy budget for signaling in the grey matter of the brain. Journal of Cerebral Blood Flow and Metabolism. https://doi.org/10.1097/00004647200110000-00001

Bhinnety, M. (2008). Struktur dan proses memori. Yogyakarta: Universitas Gadjah Mada. https://doi.org/10.22146/bpsi.7375

Bruning, R. H., Schraw, G. J., \& Norby, M. M. (2011). Cognitive psychology and instruction. History of Science. https://doi.org/10.2307/1421580

Callahan, J. L. (2010). Constructing a manuscript: Distinguishing integrative literature reviews and conceptual and theory articles. Human Resource Development Review. https://doi.org/10.1177/1534484310371492

Cardoso-Leite, P., \& Bavelier, D. (2014). Video game play, attention, and learning: How to shape the development of attention and influence learning? Current Opinion in Neurology. https://doi.org/10.1097/WCO.0000000000000077

Carrasco, M., Ling, S., \& Read, S. (2004). Attention alters appearance. Nature Neuroscience. https://doi.org/10.1038/nn1194

Chun, M. M., \& Wolfe, J. (2001). Visual attention. In E. B. Goldstein (Ed.), Blackwell's handbook 
Husnul Khotimah, Asep Supena, Nandang Hidayat

of perception (pp. 272-310). Oxford, UK: Blackwell.

Cohen, R. A. (2014). Attention. In Encyclopedia of the Neurological Sciences. https://doi.org/10.1016/B978-0-12-385157-4.00450-4

Driver, J. (2001). A selective review of selective attention research from the past century. British Journal of Psychology. https://doi.org/10.1348/000712601162103

Gabrieli, J. D. E. (1998). Cognitive neuroscience of human memory. Annual Review of Psychology. https://doi.org/10.1146/annurev.psych.49.1.87

Gardiner, J. M., \& Parkin, A. J. (1990). Attention and recollective experience in recognition memory. Memory \& Cognition. https://doi.org/10.3758/BF03197100

Hermawan, H., Samsuri, S., Kurniawati, D., Sofyaningsih, V., \& Prasetyo, D. (2018). The use of controversial public issues with video and macromedia flash player media in civic education learning. Psychology, Evaluation, and Technology in Educational Research, 1(1), 19-30. doi:http://dx.doi.org/10.33292/petier.v1i1.2

Huang, T., Le, V., Paine, T., Khorrami, P., \& Tariq, U. (2014). Visual media: history and perspectives. IEEE Multimedia. https://doi.org/10.1109/MMUL.2014.35

Jatmika, H. M. (2015). Pemanfaatan media visual dalam menunjang pembelajaran pendidikan jasmani di sekolah dasar. Jurnal Pendidikan Jasmani Indonesia, 3(1). doi:https://doi.org/10.21831/jpji.v3i1.6176

Kolb, B., \& Whishaw, I.Q. (2014). Fundamentals of human neuropsychology. UNK. https://doi.org/10.1055/s-2006-947280

Lankow, J., Ritchie, J., Crooks, \& Ross. (2014). Infografis: Kedahsyatan cara bercerita visual. Jakarta: Gramedia Pustaka Utama.

Lee, J., Lin, L., \& Robertson, T. (2012). The impact of media multitasking on learning. Learning, Media and Technology. https://doi.org/10.1080/17439884.2010.537664

Mohd, S. N., \& Muhammad, S. S. (2006). Kemahiran visualisasi: Kemahiran kognitif tahap tinngi dalam pendidikan teknik dan vokasional. Seminar Kebangsaan Pendidikan Teknik Dan Voksional 2006.

Moscovitch, M. (1992). Memory and Working-with-Memory: A Component Process Model Based on Modules and Central Systems. Journal of Cognitive Neuroscience. https://doi.org/10.1162/jocn.1992.4.3.257

Nusir, S., Alsmadi, I., Al-Kabi, M., \& Sharadgah, F. (2013). Studying the impact of using multimedia interactive programs on children's ability to learn basic math skills. E- Learning and Digital Media. https://doi.org/10.2304/elea.2013.10.3.305

Petersen, S. E., \& Posner, M. I. (2012). The Attention System of the Human Brain: 20 Years After. Annual Review of Neuroscience. https://doi.org/10.1146/annurev-neuro-062111-150525

Piran, W., \& Sasonoharjo. (2002). Media pembelajaran. Jakarta: LAN RFI.

Posner, M. I. (1993). Interaction of arousal and selection in the posterior attention network. In A. D. Baddeley \& L. Weiskrantz (Eds.), Attention: Selection, awareness, and control: A tribute to Donald Broadbent (pp. 390-405). New York, NY, US: Clarendon Press/Oxford University Press

Purwatininghandayani, S., Wahyuni, A., \& Azis, D. (2019). Penerapan pembelajaran picture and picture untuk meningkatkan motivasi dan prestasi belajar siswa sekolah dasar. Teacher in Educational Research, 1(1), 18-26. doi:http://dx.doi.org/10.26486/tere.v1i1.6

Roda, C., \& Thomas, J. (2006). Attention aware systems: Theories, applications, and research agenda. In Computers in Human Behavior. https://doi.org/10.1016/j.chb.2005.12.005

Schmidt, M. E., \& Vandewater, E. A. (2008). Media and attention, cognition, and school achievement. 
Husnul Khotimah, Asep Supena, Nandang Hidayat

Future of Children. https://doi.org/10.1353/foc.0.0004

Schraw, G., \& McCrudden, M. (2013). Information processing theory. ducation.com. https://doi.org/10.4135/97814129524 84.n349

Supardi, S., Leonard, L., Suhendri, H., \& Rismurdiyati, R. (2015). Pengaruh media pembelajaran dan minat belajar terhadap hasil belajar fisika. Formatif: Jurnal Ilmiah Pendidikan MIPA, 2(1). doi:http://dx.doi.org/10.30998/formatif.v2i1.86

Thahir, A. (2014). Psikologi belajar: Buku pengantar dalam memahami psikologi belajar. http://repository.radenintan.ac.id/845/ 1/Buku_Psikologi_Belajar_Andi_Tha hir.pdf

Treue, S., \& Katzner, S. (2010). Visual attention. Encyclopedia of Neuroscience. https://doi.org/10.1016/B978-008045046-9.00242-4

Wahyudin, W., Sutikno, S., \& Isa, A. (2016). Keefektifan pembelajaran berbantuan multimedia menggunakan metode inkuiri terbimbing untuk meningkatkan minat dan pemahaman siswa. Jurnal Pendidikan Fisika Indonesia, 6(1). https://doi.org/10.15294/jpfi.v6i1.1105 